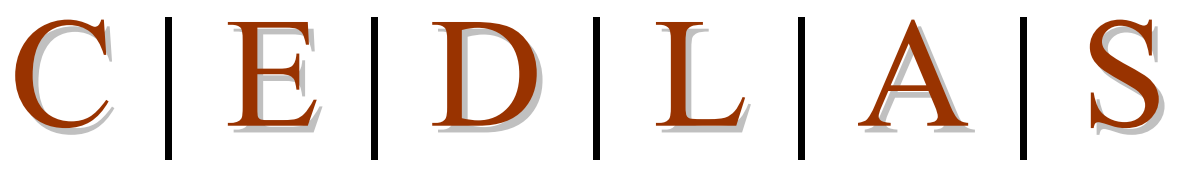

Centro de Estudios

Distributivos, Laborales y Sociales

Maestría en Economía

Facultad de Ciencias Económicas

Universidad Nacional de La Plata

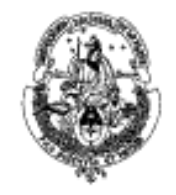

\title{
Trends in Tariff Reforms and Trends in the Structure of Wages
}

\section{Sebastian Galiani y Guido G. Porto}

Documento de Trabajo Nro. 124

Octubre, 2011

ISSN 1853-0168 


\title{
Trends in Tariff Reforms and Trends in the Structure of Wages*
}

\author{
Sebastian Galiani ${ }^{\dagger}$ \\ Guido G. Porto
}

\begin{abstract}
This paper provides new evidence on the impacts of trade reforms on wages. We first introduce a model of trade that combines a non-competitive wage setting mechanism due to unions with a factor abundance hypothesis. The predictions of the model are then econometrically investigated using Argentine data. Instead of achieving identification by comparing industrial wages before and after one episode of trade liberalization, our strategy exploits the recent historical record of policy changes adopted by Argentina: from significant protection in the early 1970s, to the first episode of liberalization during the late 1970s, then back to a slowdown of reforms during the 1980s, and finally to the second episode of liberalization in the 1990s. These swings in trade policy represent broken trends in trade reforms that we can compare with observed trends in wages and wage inequality. We use unusual historical data sets of trends in tariffs, wages, and wage inequality to examine the structure of wages in Argentina and to explore how it is affected by tariff reforms. We find that i) trade liberalization, ceteris paribus, reduces wages; ii) industry tariffs reduce the industry skill premium; iii) conditional on the structure of tariffs at the industry level, the average tariff in the economy is positively associated with the aggregate skill premium. These findings suggest that the observed trends in wage inequality in Latin America can be reconciled with the Stolper-Samuelson predictions in a model with unions.
\end{abstract}

JEL CODES: F14 F16

Key Words: Trade liberalization; Stolper-Samuelson; Wage inequality; non-competitive wages and unions.

*We thank Maria Eugenia Garibotti and Mariano Negri for excellent research assistance. Comments by O. Attanasio, J. Balat, I. Brambilla, G. Grossman, P. Goldberg, J.C. Hallak, M. Kugler, M. Olarreaga, and seminar participants at Princeton University, Stanford University, University of Virginia, and the World Bank are greatly appreciated. This project was financed by the "Behind the Border" program of the research department of the World Bank. However, the views expressed here are ours and are not necessarily shared by the World Bank or its clients. All errors are our responsibility. S. Galiani also thanks the Weidenbaum Center for financial support and the Stanford Institute for Economic Policy Research for their hospitality while he was revising this paper.

†Department of Economics, Washington University in St. Louis. email: galiani@wustl.edu

${ }^{\ddagger}$ Development Research Group, MailStop MC3-303, The World Bank, 1818 H Street, Washington DC 20433. email: gporto@worldbank.org 


\section{Introduction}

Our goal in this paper is to provide a comprehensive explanation of the links between trade reforms and wages in developing countries. While there is certainly a very voluminous literature on this topic, two novel features differentiate our paper: the theoretical framework that we use to motivate and guide our analysis, and the data tailored for this project. These differences, we believe, are two valuable contributions of our work.

Theoretically, the notion that trade affects wage inequality stems largely from the Stolper-Samuelson theorem and the Heckscher-Ohlin model of trade. Countries specialize in the production of those goods that use intensively the abundant factors of production. In its simplest form, the theorem states that while developed countries specialize in the production of skilled intensive goods, developing countries specialize instead in goods that use intensively unskilled labor. One key implication of this model is that trade liberalization should lead to an increase in the skilled wage premium in developed countries and a corresponding decline in developing countries.

The Stolper-Samuelson prediction is at odds with most of the empirical literature on the impacts of trade liberalization and wage inequality in Latin America, which in fact shows that tariff liberalization has increased the disparity in labor earnings between skilled and unskilled workers. Examples include Feliciano (2001), Galiani and Sanguinetti (2003), Goldberg and Pavcnik (2004), Harrison and Hanson (1999), Revenga (1997), and Robertson (2004). ${ }^{1}$ The leading argument advanced to account for the discrepancy between the model and the data is the dependency of the impacts of trade liberalization on the initial structure of tariffs. If protection is initially granted in those sectors that use unskilled labor more intensively, then trade liberalization might cause relative unskilled wages to decline and wage inequality to increase. $^{2}$

In this scenario, we ask whether it is possible to preserve the Stolper-Samuelson

\footnotetext{
${ }^{1}$ For developed countries, the Stolper-Samuelson result is supported by Sachs and Shatz (1994) and Leamer (1998) but it is disputed by Lawrence and Slaughter (1993).

${ }^{2}$ Other mechanisms behind the observed increase in wage inequality after trade liberalization are skilled biased technical change induced by openness and skill complementarity of capital goods or imported materials. See Attanasio, Goldberg and Pavcnik (2004), Goldberg and Pavcnik (2005), Feenstra and Hanson (1999), and Pavcnik (2003).
} 
mechanism, and we claim that we can actually do that by expanding the basic factor abundance model to incorporate elements from labor economics. The literal Heckscher-Ohlin view of trade and wage inequality assumes the existence of competitive labor markets with perfect intersectoral factor mobility. This implies that the wages of workers with the same skills should equalize across sectors and that wages should change in the same way in all firms, independently of their internal features and reflecting only overall external market conditions. These predictions are, however, in sharp contrast with the evidence on wage differentials, even for similar individuals, documented by Dickens and Katz (1986) and Krueger and Summers (1988), and more recently by Attanasio, Goldberg and Pavcnik (2004) within the trade literature. Further, Gibbons and Katz (1989) and Krueger and Summers (1988) suggest that these wage premiums cannot be fully explained by compensating differentials alone, thus acknowledging the role of other explanatory factors such as sector-specific human capital, unionization, profit sharing or bargaining between workers and firms. Moreover, there is evidence to indicate that these wage premiums can in part be affected by trade. Dickens and Lang (1988) and Gaston and Trefler (1994) find that the industry premiums are correlated with trade flows in the U.S., and Attanasio, Goldberg and Pavcnik (2004) and Goldberg and Pavcnik (2005) establish a similar link with sectoral tariffs.

It follows that a useful new model of trade and wages should combine a factor abundance hypothesis with inter-industry wage differentials. Our model thus works with an unskilled labor abundant country that in consequence exports unskilled intensive goods and imports skilled intensive goods. This feature of the model generates a Stolper-Samuelson type prediction: conditional on the cross-section structure of protection, the economy-wide skill premium moves in the same direction as the average tariff in the economy. However, wages do not equalize across sectors. While this could also be the consequence of imperfect labor mobility, here we emphasize the role of non-competitive wage setting mechanisms. ${ }^{3}$ In particular, we assume that the wage setting for unskilled labor in the import competing sector is non-competitive. A union bargains for a fraction of the tariff rent and then distributes it among unskilled workers in the import sector, who thus enjoy a wage premium over similar

\footnotetext{
${ }^{3}$ Sector wages bargained by unions are quite prevalent in the case study for Argentina that we investigate below (see Galiani and Nickell, 1999).
} 
workers in the export sector. Even with competitive labor markets for skilled workers, this feature of the model generates differences in the skill premium at the industry level that, in turn, depend negatively on the industry tariff. Thus, the model predicts that, conditional on aggregate protection, sectoral skill premiums and sectoral tariffs move in opposite directions.

In the current literature on trade and wages, identification generally follows from few cross-sections of industry tariffs and wages of skilled and unskilled workers. However, with few cross-sections, the estimated coefficients may confound unobserved effects and unaccounted simultaneous policy reforms. This is a major concern in Latin America during the 1990s, a period when most countries implemented several concurrent reforms. Further, when there are short-run departures from Heckscher-Ohlin, like in our model, it is not possible to identify Stolper-Samuelson effects from only a few cross-sections because the time dimension of the data becomes essential to separate the different forces in place. We overcome these issues by setting up historical data sets of trends in trade reforms, trends in wages, and trends in skill wage premiums in Argentina. Our data span the period 1974-2001. We construct a time series of tariffs, for different sectors in different years, and a time series of labor force surveys with data on individual wages. This is the first instance in this literature in which such a historical record of trade reforms is combined with a comparable micro data set of workers and wages. ${ }^{4}$ The outcome is almost 30 years of data on sectoral tariffs and individual wages.

With these data, we can pursue a stronger identification strategy by exploring the recent historical record of trade policy changes adopted by Argentina during the last 30 years: from significant protection in the early 1970s, to the first trade liberalization episode in the late 1970s and early 1980s, then back to a slowdown of tariff cuts in the 1980s, and finally to the second liberalization of the 1990s (which included Mercosur, a regional trade agreement among Argentina, Brazil, Paraguay, and Uruguay). These swings in trade policy generate broken trends in tariff reforms that we can compare with observed trends in wages. This encompasses a different, useful, and credible identification strategy. Further, we can exploit

\footnotetext{
${ }^{4}$ The work by Attanasio, Goldberg, and Pavcnik (2004) and Golberg and Pavcnik (2005) is similar to ours in that it exploits data from the eighties and the nineties. There is a major difference, though. Whereas their study involves one trade reform, we study two episodes of trade liberalization separated by a reversal to protection.
} 
both our cross-section variability in sectoral tariffs as well as our time-series variability in the average national tariff to better uncover the presence of Stolper-Samuelson effects on the structure of wages. We propose to extract Stolper-Samuelson effects using the time series of the average national tariff once the effects of sectoral tariffs on the structure of wages are controlled for. Our data, which combines a times series of cross-sections and tariffs, provide us with a unique opportunity to establish this result.

Our findings are as follows. First, we find that, for a given aggregate level of tariff protection (that is, keeping constant the average national tariffs) sectoral tariffs protect sectoral workers (so that, ceteris paribus, a reduction in the tariff accrued to a particular sector leads to a decrease in wages). Further, after controlling for individual worker characteristics, period effects, industry effects, and time-varying skill premium effects, we find a strong negative association between tariffs and the skill premium at the industry level. This implies that sectoral tariffs benefits sectoral unskilled labor. Second, we are able to trace Stolper-Samuelson effects in the structure of wages. After controlling for the structure of tariffs at the industry level, the average tariff in the economy is positively associated with the economy-wide skill premium over time. This implies that trade liberalization can actually benefit the abundant factor which, in developing countries, is unskilled labor.

The remainder of the paper is organized as follows. In Section 2, we describe the data used in this paper and we motivate our work by describing the trends in trade liberalization and the trends in wage inequality in Argentina. In Section 3, we lay out one theoretical framework that is consistent with the basic trends found in the data. In Section 4, we present our regression analysis. Section 5 concludes.

\section{Tariff Reforms and the Structure of Wages}

A major input into our analysis is the historical data on Argentine trade policy and wages, spanning the 1974-2001 period. These data come from two different sources: customs data on imports and tariffs at the sectoral level, and household survey data on wages and workers.

We begin by describing the customs data. We measure trade policies with sectoral tariffs. 
Data on ad-valorem import tariffs come from official Tariff Schedules, which specify the tariff rate levied on each item of the Harmonized System (HS). In order to make our trade data comparable with the wage data, we need to build tariff measures at the 3-digit level of the International Standard Industrial Classification (ISIC). To do this, we first match each heading in the HS with its closest equivalent in the ISIC classification. We then aggregate the HS data to build measures of tariffs at the 3-digit level. To perform the aggregate, we start from the next-to-lowest subheading, calculate the median of the item belonging to it, and iterate on this procedure. ${ }^{5}$ We end up with a panel data set of import tariffs for the manufacturing sector across time. Figure 1 provides some insights into the nature of trade policy and trade reform in different years. It depicts key percentiles of the distribution of import tariffs.

The recent historical Argentine trade policy is characterized by at least three different periods. Our starting point in 1974 was one of high protection, with average tariffs in excess of 100 percent, and sectors with median rates in excess of 200 percent. Starting in 1976, tariffs were abruptly reduced. The average tariff was cut by two thirds in three years, dropping from slightly above 100 percent in 1976, to 47 percent in 1978 and to 32 percent in 1979. In addition, the whole distribution shifted downwards with respect to 1974 .

The trend in trade reforms is broken in 1982 when there was a slight increase in average tariffs that continued all throughout the eighties. Notice, however, that trade policy is not limited to tariffs but includes non-tariff barriers like quotas, or quantitative restrictions. Although we were unable to construct adequate measures of non-tariff barriers for the period under analysis, the historical accounts on the use of quantitative restrictions in Argentina (Berlinski, 1994; Berlinski, 2003) reveal a heavy use of quotas until 1959, when they were eliminated. Quotas were reinstated in 1982 and maintained all through the 1980s until they were again fully eliminated in 1989-1990 as a pre-requisite to Mercosur negotiations. The reversal of trade policy during this period is thus more evident in quotas than in tariffs.

In contrast, tariff rates were reduced in 1990 and 1991, remaining below 20 percent

\footnotetext{
${ }^{5}$ See the Data Appendix in the working paper version (www.sites....COMPLETAR) for further details on sources of information, the matching of Harmonized System and ISIC classification, and the aggregation procedure.
} 
Figure 1

Distribution of Median Tariffs per 3 digit sector

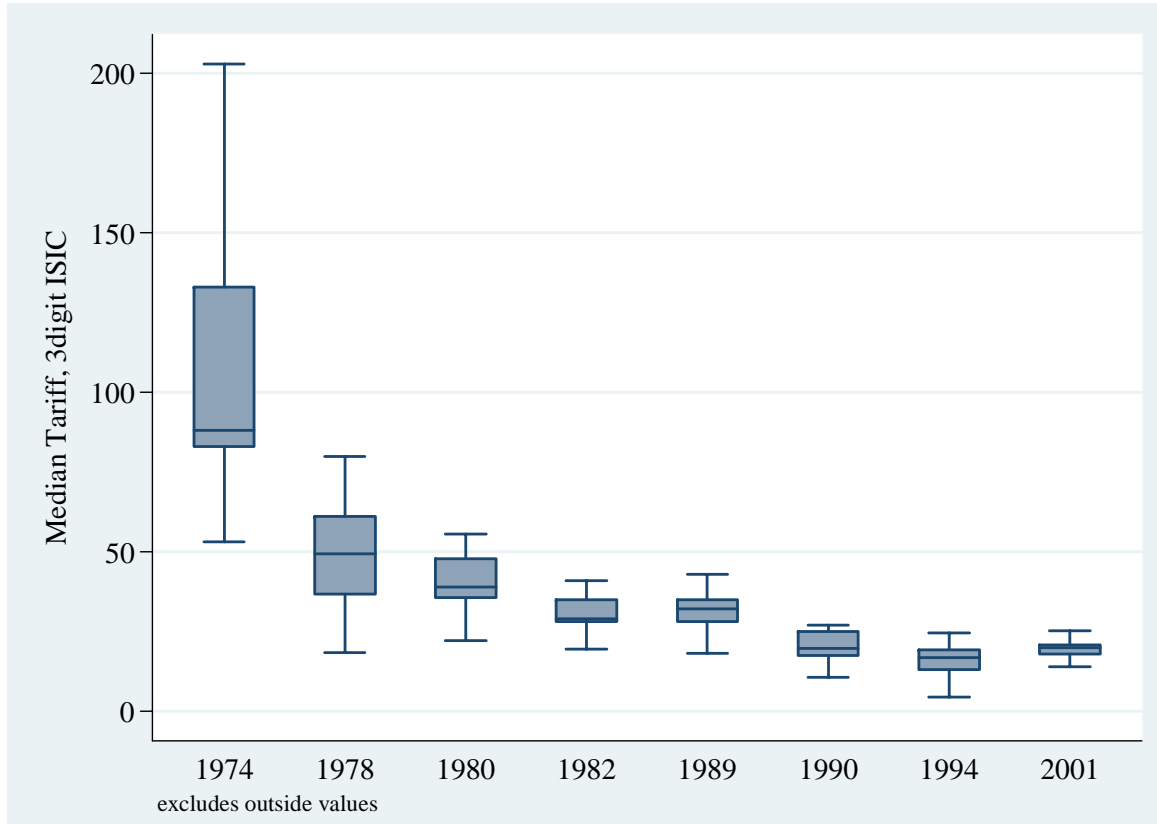

Note: Distribution of tariffs at the 3-digit ISIC manufacturing sector for selected years. The horizontal line within each box is the median tariff in each year. The borders of the boxes are the 25th and 75th percentiles of the tariff distribution. The horizontal bars outside the boxes are the "adjacent values." The upper adjacent value is the largest data value that is less than or equal to the sum of the 75th percentile and 1.5 times the interquantile range. The lower adjacent line is the smallest data value that is greater than or equal to the different between the 25th percentile and 1.5 times the interquantile rage. The box plot does not show the "outside values," values exceeding the upper and lower adjacent values. Quantiles are calculated weighting each sector by its employment level.

throughout all the 1990s decade. In 1994, Mercosur was adopted and tariffs were further reduced. However, in an attempt to prevent a fiscal crisis, there was a slight increase in protection in 2001 .

We turn now to the labor force data. The standard source of individual data on labor earnings and worker characteristics in Argentina is the Permanent Household Survey (EPH, Encuesta Permanente de Hogares). This is a household survey with information on wages, employment status, and individual and family characteristics. The data are usually collected twice a year, in May and October. The EPHs of the 1990s have been already used in the literature but, for our purposes, we needed to track the surveys back into the 1970s and 1980s. We were able to compile 40 EPH surveys. ${ }^{6}$ We have data for all years, except for

${ }^{6}$ The Data Appendix in the working paper version (www.COMPLETAR) provides a brief description of the different data sets used here and their sample sizes. 
1979, 1983, and 1984. For years 1974, 1976, 1977, 1978, 1981, 1985, 1986, and 1992, we only have information for October (and thus not for May). In contrast, in 1980 and 1982, we use data on May but not on October.

Before launching our formal econometric investigation, we provide next snapshots of the main features of the data. To do that, we casually inspect our data to report prima facie evidence on the relationship between the trends in tariff reforms and the trends in the structure of wages in Argentina. We begin with the "tradable premium." If firms in the import competing sectors take the outside opportunity of workers as given but pay a wage premium, which may be due to the protection granted by sectoral tariffs, we should see in the data that firms in the tradable sector cannot pay less than the competitive wage paid by firms in unprotected sectors. Figure 2 reveals evidence in favor of the "tradable premium" in our data. The figure depicts the coefficient of a tradable dummy, for different years from 1974 to 2001, in a standard earnings equation (after controlling, in each year, for age, age squared, gender, marital status and a set of education dummy variables). With a few exceptions, the estimated tradable premiums are always positive in our data.

Further, Figure 2 reveals that the tradable premium is likely to depend inversely on the level of aggregate protection. In fact, the average tradable sector wage premium is decreasing during the 1970s (the first episode of trade liberalization in Argentina), increasing during the 1980s (the reversal episode of quota use and stagnation of tariff cuts), and decreasing again during the 1990s. This is the first trend uncovered by our data.

The second major trend of interest involves the aggregate skill premium at the national level. To document this, we restrict our sample to tradable manufacturing sectors only. We compute the skilled wage premium by defining three educational categories: skilled labor, which comprises workers who have finished college, semiskilled labor, which consists of workers who have finished secondary school (and may have incomplete college education), and unskilled labor, which includes workers with no schooling, complete and incomplete primary education, and incomplete secondary education. The skill premium is calculated as the coefficient on the skilled dummy in a standard earnings regression. Concretely, we ran separate regressions of wages on the skill dummy for one survey in each year, controlling for 
Figure 2

The Tradable Premium

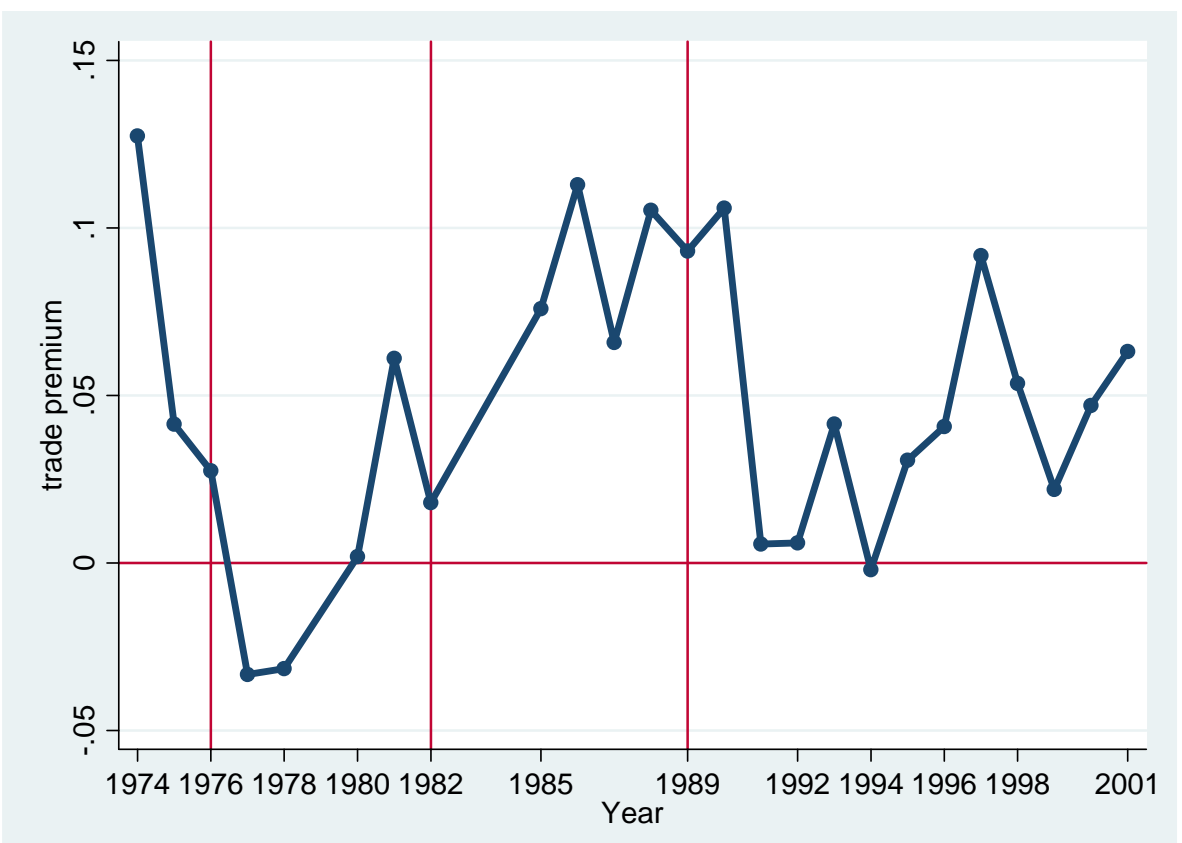

Note: own calculations based on historical trade data and labor surveys (EPH). The graph shows estimates of the "trade" premium. For each year in the sample, an earnings regression of log wages on age, age squared, gender, marital status, educational dummies and a tradable sector dummy is estimated. The coefficient of the tradable dummy is defined as the "trade premium"; it accounts for the premium, over the non-tradable sector, paid in sectors exposed to international trade. 
Figure 3

Trends in Tariffs and in Wage Premium

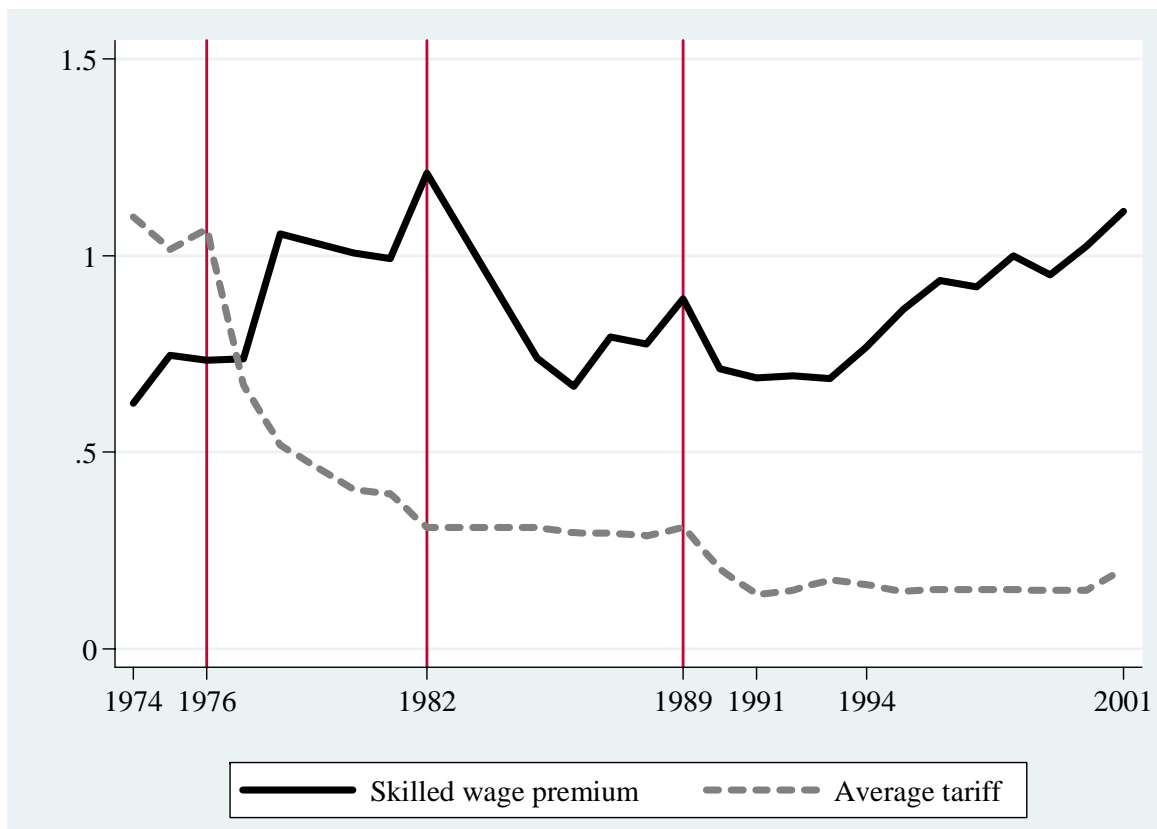

Note: own calculations based on historical trade data and labor surveys (EPH). Tariff: average tariff across all 3-digit ISIC sectors, weighted by employment in each sector. Skilled wage premium: coefficients on the skilled dummy in different earnings regressions per year. See text for more details.

age, age squared, gender and marital status. Notice that we do not include trade related variables at this point. ${ }^{7}$

Figure 3 reveals the breaks in trade liberalization trends and the breaks in the wage inequality trends. The broken line corresponds to the evolution of the average tariff during the period 1974-2001. The figure clearly shows the initial high protection on the early 1970s, the liberalization of the late 1970s, the stagnation of tariffs during the 1980s, and the last episode of liberalization of the 1990s.

The solid line in Figure 3 depicts the skill premium. ${ }^{8}$ There is a sharp increase in the wage differential between skilled and unskilled workers between 1974 and 1982, coinciding with the

\footnotetext{
${ }^{7}$ One concern is the relevance of college degrees in the 1970 s when a lower fraction of the population attained those degrees. To account for this, in the regression analysis of Section 4, we also work with an alternative definition of skills that merges workers with both secondary and college education. Our main findings are robust.

${ }^{8}$ Note that we report the estimated coefficient directly -i.e., without the standard exponential transformation $\left(e^{\text {coefficient }}-1\right)$.
} 
first wave of trade policy reforms. While individuals with college education earned roughly 60 percent more than their unskilled counterparts in 1974, the difference grew to about 120 percent in 1982. Between 1982 and 1989, when trade liberalization lost momentum, the skill premium decreased markedly. In contrast, the skill premium resumed its upward course during the 1990s, coinciding with the second episode of trade liberalization. Thus, prima facie, there is evidence of a correlation between the skilled premiums and the tariffs.

Our last observation relates to the skill premium at the industry level. In the Argentine data, the inter-industry wage differentials of Dickens and Katz (1986), Krueger and Summers (1988), and Attanasio, Goldberg and Pavcnik (2004) vary with the skill level so that there are skilled premiums at the industry level. For our purposes, the main features of these premiums is that they correlate negatively with the sectoral tariffs. To see this, we estimate a sectoral skill premium for each manufacturing industry after pooling the data for all years. This regression includes a full set of industry dummies, skill dummies, individual characteristics, and survey effects. The output of interest is a set of interactions between the skilled dummies (for college education) and the industry dummies that measure the average skilled industry premium in the sample. In Figure 4, we plot these premiums against the average tariff in each sector in the sample. The graph gives a clear hint of a negative relationship between the sectoral tariff and the skilled industry premium.

\section{A Simple Theoretical Framework}

Our aim in this section is to introduce a theoretical model to reconcile Stolper-Samuelson effects with the existence of skilled premiums at the industry level and to account for the correlations observed in Argentina (and in several Latin American countries) between trade liberalization and wage inequality. Thus, we want to develop an analytical framework that merges two key mechanisms: the economic logic of neoclassical models of trade (like Heckscher-Ohlin) and the existence of (skilled) wage premiums at the industry level. Based on the trends in Figure 3 and the pattern of tariffs and industry-skill premiums in Figure 4, we claim that a useful model of trade protection and wage inequality should embed both 


\section{Figure 4}

The Skill Premium at the Industry Level and Sectoral Tariffs

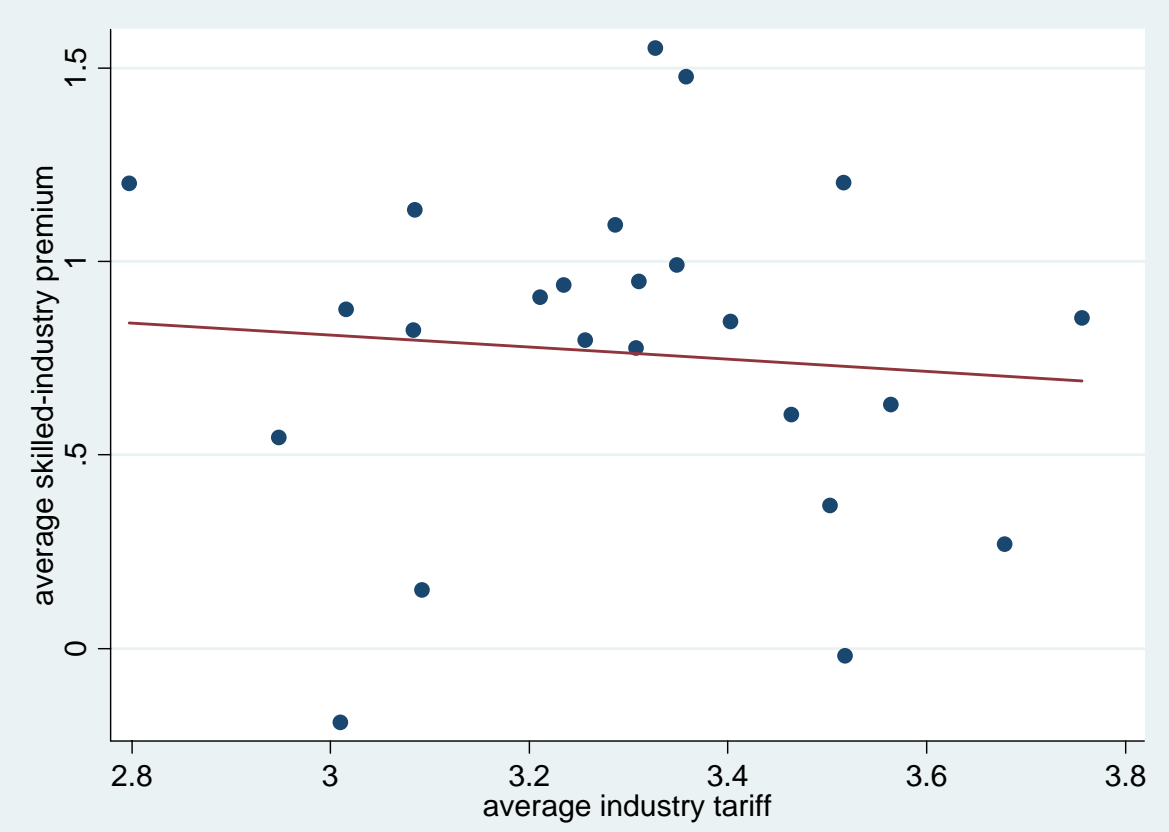

Note: own calculations based on historical trade data and labor surveys (EPH). Tariff: average tariff for each 3-digit ISIC sector across years (1974-2001). Skilled-industry premium is the coefficient of an interaction between the skilled dummy and the industry dummies in the pooled EPHs across years. 
typical explanations of the pattern of trade and inter-industry wage differentials. We propose to do this by combining a factor abundance hypothesis with a non-competitive wage setting mechanism in import competing sectors. In particular, we allow wages in import sectors to be determined by the bargaining power of unions. Although similar predictions can be derived with models of imperfect factor mobility or profit sharing, a model with unions seems more relevant for our empirical analysis on Argentina, where the presence of unions in the manufacturing sector is widespread (Galiani and Nickell, 1999).

The role of unions in our model is to protect unskilled workers. There is strong evidence that unions actually compress the wage distribution, particularly from below (Freeman, 1982). That is, unions raise the wages of workers who, on spot labor markets, would earn relatively low wages. This is because unions raise wages above market clearing levels whenever market clearing wages are close to the reservation wage (Vogel, 2007). Card et al. (2003a) present evidence on union wage compression for the U.S., the U.K. and Canada; Stephan and Gerlach (2005) present evidence for continental Europe (see, also, Card et al. (2003b) and Blau and Kahn (1996)). Marshall (2001) presents evidence that documents the wage compression induced by unions in Argentina.

For simplicity, we work with two tradable sectors, $i=1,2$. At this point, the best way to think about these sectors is as aggregate exportable and importable sectors. (We indicate how to expand the model to various importable sectors below). There is also a non-tradable sector, denoted with 0 . There are two factors of production with fixed supply, skilled $S$ and unskilled $U$ labor. The country is small and takes international prices $p_{i}^{*}$ as given. The price of the non-traded good is determined endogenously.

Sector 2 is skilled intensive:

(1) $\frac{a_{2 s}}{a_{2 u}}>\frac{a_{1 s}}{a_{1 u}}$,

where $a_{i u}$ and $a_{i s}$ are the technological requirements of unskilled and skilled labor, respectively, in sector $i$. Since the country is relatively abundant in unskilled labor, the unskilled intensive good 1 is exported and the skilled intensive good 2 is imported. This is the standard factor abundance, Heckscher-Ohlin prediction. 
Labor is perfectly mobile across sectors. The market for skilled labor is competitive in all sectors with equilibrium wage $w_{s}$. The market for unskilled labor in the non-tradable and exportable sector 1 is also competitive, with equilibrium wage $w_{u}$. The zero-profit condition in sector 0 is

$$
p_{0}=w_{s} a_{0 s}+w_{u} a_{0 u}
$$

where $p_{0}$ is the price in domestic currency. The corresponding zero-profit condition in the export sector is

$$
p_{1}=w_{s} a_{1 s}+w_{u} a_{1 u}
$$

where $p_{1}$ is expressed in domestic currency. The aggregate import competing sector behaves differently. First, the sector can be protected by tariffs, denoted by $t$. This is best interpreted as the average national tariff across several import sectors. Second, in sector 2 there is a union that represents unskilled labor. To model the role of unions, but at the same time to depart as little as possible from the standard model, we adopt a simple rule for the behavior of unions and the wage setting mechanism. ${ }^{9}$ This rule works as follows. In the absence of a tariff in sector 2 , free entry and zero profits imply that $p_{2}^{*}=w_{s} a_{2 s}+w_{u} a_{2 u}$. With a tariff $t$, firms face a price $p_{2}=p_{2}^{*}(1+t)$ and, keeping factor prices constant, would enjoy instantaneous profits equal to $p_{2}^{*} t$. We call this the "tariff rent."

Unions negotiate with incumbent firms and successfully appropriate a fraction $\alpha \in[0,1]$ of these rents. ${ }^{10}$ This income is then transferred to unskilled workers in sector 2 via a premium

\footnotetext{
${ }^{9}$ An explicit model of the bargaining mechanism of firms and unions requires profits in equilibrium. This, in turn, would require either adding one (fixed) factor to collect those profits or departing from competition (as in a model with monopolistic competition). For example, Gaston and Trefler (1995) build a model where unions bargain wages above market clearing conditions in order to share rents generated in non-competitive product markets. While we could have followed a similar approach here, we opted for the model presented here to prioritize simplicity. All our qualitative results hold in these more complicated models as well.

${ }^{10}$ In Argentina, unions negotiate with different Manufacturing Chambers that essentially represent incumbent producers.
} 
over the competitive wage in both the non-tradable and export sectors $w_{u}$. Formally,

$$
w_{2 u}=w_{u}+\alpha \frac{p_{2}^{*} t}{a_{2 u}}
$$

The second term on the right hand side of (4) is thus the tariff rent appropriated by the union per unit of unskilled labor. For simplicity, we assume that $a_{2 u}$ is given at its equilibrium level when unions compute the tariff rent.

Once unions secure this fraction of the "tariff rent," competitive forces begin to work as in the standard Heckscher-Ohlin model. This means that the extra-profits generated by the tariffs (the part not appropriated by the unions) will attract entrants into the import competing sector, which will expand and thus demand more skilled and unskilled labor (the export sector will instead contract and release those factors). In the end, competitive wages $w_{s}$ and $w_{u}$ will adjust until those profits dissipate completely. In equilibrium, thus, this free entry condition translates into an ex-post zero-profit condition in sector 2

$$
p_{2}=w_{S} a_{2 s}+w_{2 u} a_{2 u}
$$

This is a simple $2 \times 2$ model of trade with a non-tradable sector. Given the prices of the tradable goods, the system determines the competitive wages for skilled and unskilled labor $w_{s}$ and $w_{u}$. The zero profit condition in the non-traded sector determines $p_{0}$. Lastly, the wage-setting rule determines the unskilled wage in the import competing sectors.

To investigate how the structure of wages depends on the structure of protection, totally differentiate (3), (4) and (5) to get

(6) $\theta_{1 s} \widehat{w}_{s}+\theta_{1 u} \widehat{w}_{u}=0$

(7) $\quad-\left(w_{u} / w_{2 u}\right) \widehat{w}_{u}+\widehat{w}_{2 u}=\left(\alpha / \theta_{2 u}\right) \tau \widehat{t}$

(8) $\theta_{2 s} \widehat{w}_{s}+\theta_{2 u} \widehat{w}_{2 u}=\tau \widehat{t}$,

where $\tau=\frac{t}{1+t}, \widehat{x}=d x / x$, and $\theta_{i s}=\left(a_{i s} w_{s}\right) / p_{i}, i=1,2 ; \theta_{1 u}=a_{1 u} w_{u} / p_{1} ;$ and $\theta_{2 u}=$ 
$a_{2 u} w_{2 u} / p_{2}$. Our skilled intensity assumption of sector 2 implies that $B=\theta_{1 s} \theta_{2 u} \frac{w_{u}}{w_{2 u}}-\theta_{1 u} \theta_{2 s}<$ 0. The solution for the changes in wages is thus

(9) $\frac{\widehat{w}_{s}}{\widehat{t}}=-\frac{1}{B} \tau \theta_{1 u}(1-\alpha)>0$,

(10) $\frac{\widehat{w}_{u}}{\widehat{t}}=\frac{1}{B} \tau \theta_{1 s}(1-\alpha)<0$

(11) $\frac{\widehat{w}_{2 u}}{\widehat{t}}=\frac{1}{B} \tau \theta_{1 s} \frac{w_{u}}{w_{2 u}}\left(1-\alpha \frac{a_{1 u}}{a_{1 s}} \frac{a_{2 s}}{a_{2 u}}\right) \gtrless 0$.

Note that, provided $\widehat{t}>0, \widehat{w}_{2 u}>\widehat{w}_{u}\left(\widehat{w}_{2 u}<\widehat{w}_{u}\right.$ otherwise).

Several key results, depicted in Figure 5, emerge from our simple model. Since factor abundance plays a role in determining the pattern of trade, the model delivers a Stolper-Samuelson prediction. An increase in the (average) tariff causes sector 2 to expand and demand factors of production and this in turn affects factor prices. Since sector 2 is intensive in skilled labor, an increase in $t$ generates an increase in the skilled wage (equation 9 ) and a reduction in the competitive unskilled wage (equation 10). In consequence, increases in tariffs cause the skill premium to increase so that trade liberalization should lead to a decline in wage inequality.

In Figure 5, the initial equilibrium is at $a$. An increase in $t$ shifts the curve defined by $p_{2}^{*}[1+t(1-\alpha)]=w_{s} a_{2 s}+w_{u} a_{2 u}$ up. As a result, $w_{s}$ increases and $w_{u}$ declines. Notice that the increase in the tariff $t$ causes the unskilled wage in sector 2 to increase above the equilibrium $w_{u}$. In the end, $w_{2 u}$ could increase or decrease, depending on the response of the competitive wage and on the power of unions to extract tariff rents. If unions can appropriate all the instantaneous tariff rents $(\alpha=1)$, then neither $w_{s}$ or $w_{u}$ would change and $w_{2 u}$ would instead increase by the full magnitude of the tariff rent.

A number of additional results follow from comparing the structure of wages brought about by the unions. The model predicts that sectors protected by tariffs pay higher wages. To see this, notice that unskilled wages in the protected sector are actually higher than in the non-tradable and export sectors. This is consistent with the "trade premium" in Figure 2. Further, the wedge between $w_{2 u}$ and $w_{u}$ is increasing in the average tariff $t$. This means 
Figure 5

Tariffs, Unions and Wages

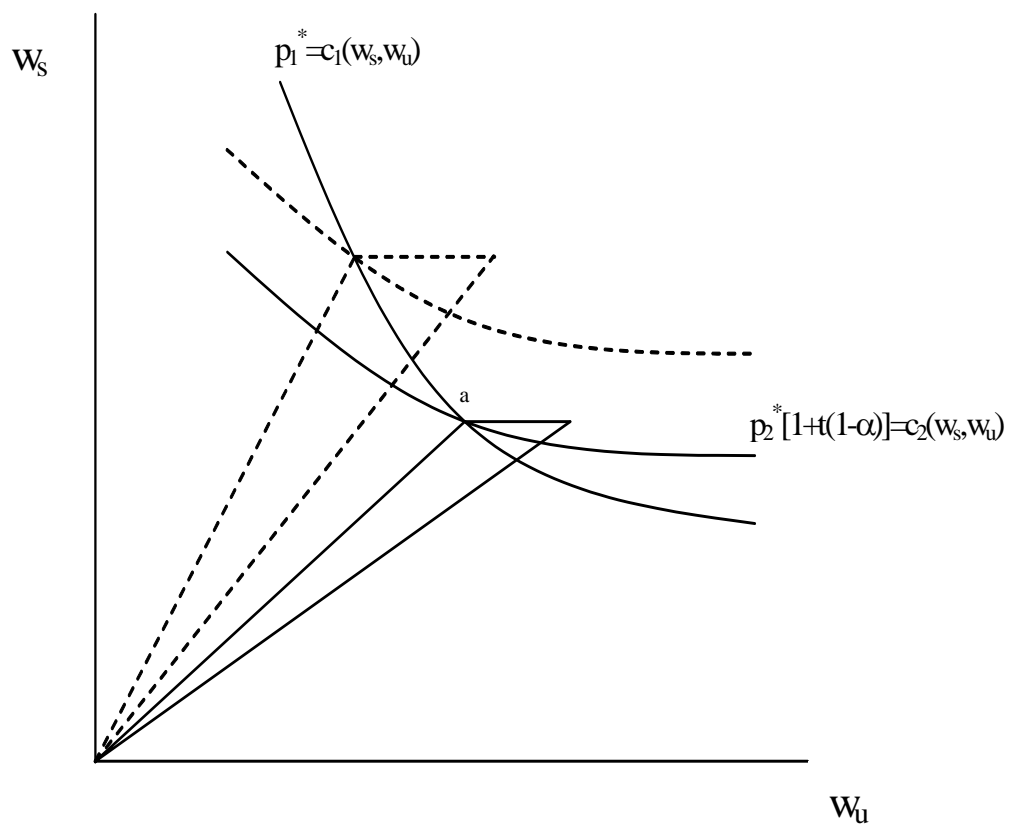

Note: Equilibrium wages for skilled and unskilled workers in the presence of unions. Not drawn to scale.

that these "trade premiums" should themselves depend on sectoral tariffs, as suggested by Figures 1 and 2 .

For simplicity, we have worked so far with a $2 \times 2$ model. With more sectors and/or factors, the strong predictions of the Stolper-Samuelson theorem do not hold: only statements about correlations between factor intensities, product price changes and factor price changes can be established. However, it is worth making further abstractions in the model to derive some predictions regarding the structure of protection and wages across import sectors. Clearly, the model suggests that, within the import sector, those more heavily protected are likely to pay even higher unskilled wages. A corollary of this result is that since all sectors pay the same wages for skilled labor, the model predicts the existence of different skill premiums at the industry level. Moreover, this skill premium depends on the sectoral tariff $t$ (and on the sectoral power of unions as well).

This can be more formally seen as follows. Assume there are two import competing 
sectors, $x$ and $y$. Both sectors are protected by tariffs $t_{x}$ and $t_{y}$ (so that the average tariff is $t=\phi_{x} t_{x}+\phi_{y} t_{y}$ given weights $\phi_{x}$ and $\phi_{y}$ ). Both sectors are protected by unions, and the wage setting rules are ${ }^{11}$

$$
w_{j u}=w_{u}+\alpha_{j} \frac{p_{j}^{*} t_{j}}{a_{j u}}
$$

for $j=x, y$. To inspect the implications of the model, we can, for example, change the structure of tariffs $t_{x}$ and $t_{y}$ while keeping the average tariff $t$ constant. In principle, this should not affect competitive wages in the export (and non-tradable) sector. However, the structure of unskilled wages within the import sector does change. Differentiating (12) with respect to $t_{x}$ and $t_{y}$, while holding $t$ constant (so that $\phi_{x} d t_{x}+\phi_{y} d t_{y}=0$ ), we get

$$
\widehat{w}_{x u}=\left(\alpha_{x} / \theta_{x u}\right) \tau_{x} \widehat{t}_{x}
$$

and

$$
\widehat{w}_{y u}=-\left(\alpha_{y} / \theta_{y u}\right) \tau_{y}\left(\phi_{x} / \phi_{y}\right) \widehat{t}_{x}
$$

An increase in the protection granted to sector $x$ causes the unskilled wage in sector $x$ to increase and the skilled premium in that sector to decline. In addition, while the tariff in sector $y$ drops, the unskilled wage declines and the skilled premium instead increases. In consequence, the model predicts an inverse relationship between the sector tariff and the industry skill premium. This is consistent with the correlations revealed in Figure 4.

A model with imperfect labor mobility is the leading competing hypothesis to our model with unions. While unions have been prevalent in Argentine history, there is also evidence that labor is not fully mobile as in many other developing countries. There are some peculiar issues with factor specificity, though. The simplest possible model would allow for imperfect mobility of unskilled labor (and perfect mobility of skilled labor). In this context, it is easy to see how sectoral tariffs would raise unskilled wages in protected sectors so that, together

\footnotetext{
${ }^{11}$ The average unskilled wage in the import sector would be $w_{2 u}$ as defined above.
} 
with equalized inter-sectoral skilled wages, this model would work exactly as our union model. If, instead, unskilled labor is perfectly mobile but skilled labor is not, then factor specificity is not enough to deliver predictions that are consistent with the trends observed in our data. Some sort of non-competitive wage setting would be required. Unions can play such a role in a hybrid model of trade, unions, and factor specificity. Finally, another option is to allow both skilled and unskilled labor to be imperfectly mobile. To accommodate the Heckscher-Ohlin trends, however, such a model should contain dynamic features whereby factor specificity is gradually lost, as in Mussa (1978). In any case, our choice of developing a model with unions rather than with factor specificity is guided by both plausibility and simplicity. As argued, our aim is to have a framework to understand the trends of section 2 and the regression results that we discuss next. ${ }^{12}$

\section{The Impacts of Tariffs on wages}

In this section, we investigate econometrically the main features of our data revealed by the snapshots of the previous section. These snapshots first show that, ceteris paribus, sectors protected by tariffs should pay higher wages. In addition, in the Argentine data, there seems to be a skill premium at the industry level that is partly explained by the level of tariff protection. This suggests the existence of (short-run) departures from the standard Heckscher-Ohlin model and, in our theoretical framework, this role is played by sectoral unions. In consequence, any attempt to infer Stolper-Samuelson effects with only a few cross-sections of industry wages will be clouded by those same departures from the standard model. Instead, it would be possible to identify those effects once the sectoral structure of protection is accounted for. That is, conditional on the structure of tariffs at the industry level, we should find that the average national tariff affects relative wages according to the Stolper-Samuelson theorem and the Heckscher-Ohlin model of trade. ${ }^{13}$

\footnotetext{
${ }^{12}$ Naturally, there could also be other forces at work. For instance, Atolia (2007) develops a dynamic model with complementarities between capital and skills that also suggests short-term departures from Stolper-Samuelson results and long-term Stolper-Samuelson trends. Bustos (2005) provides empirical results for Argentina consistent with this view.

${ }^{13}$ Notice that, although we are able to test the predictions that are consistent with our model, given the available data, we are unable to fully investigate the mechanisms indicated in section 3 - for instance, unions
} 


\subsection{Trade Protection: Tariffs and Industry Wages}

In our model, protected sectors pay higher wages. In section 2 , we motivated this prediction by showing that the tradable premium (the coefficient of a dummy for tradable industries in a standard earnings equation) was positive. To further investigate this prediction, we begin with a simple econometric model in which sectoral tariffs affect industry wages (without distinguishing between skilled and unskilled industry premiums at this moment).

We regress the $\log$ of the wage of individual $i$, in industry $j$, at time $t,\left(\ln w_{i j t}\right)$, on the $\log$ of the tariff in industry $j$ at time $t, \ln \tau_{j t}$, an indicator of skill level $d S_{i g j t}$ (where $d$ stands for dummy indicators and $g$ indicates whether the worker is skilled, semiskilled, or unskilled), and a number of other individual characteristics $\left(\mathbf{x}_{i j t}\right)$ including age, gender, and marital status. Thus, the model that we estimate is

$$
\ln w_{i j t}=\mathbf{x}_{i j t}^{\prime} \beta_{t}+\sum_{g} \delta_{g t} d S_{i g j t}+\alpha \ln \tau_{j t}+I_{j}+Y_{t}+\mu_{i j t}
$$

where $I_{j}$ is an industry fixed effect, $Y_{t}$ is a survey-period fixed effect, and $\mu_{i j t}$ is the error term. As explained in section 2, we use data on sectoral tariffs at the 3-digit level.

We report findings from four different econometric models. In Model 1, the returns to schooling $\left(\delta_{g}\right)$ and tenure are constant across time; in Model 2, the returns to schooling are allowed to vary from survey to survey $\left(\delta_{g t}\right)$, but the returns to age are not time-varying; in Model 3, both the returns to schooling and the returns to age vary across surveys. In Model (4), we further allow for a sectoral linear trend in the model to control for possible trends in the change in wages that might be a confounding factor for the impact of tariffs. A nice feature of our study is that the two episodes of trade liberalization that we exploit to identify the effect of tariffs on wages are separated in time by approximately a whole decade. This gives us enough variability to disentangle, by exploiting the within sector variability in tariffs, the effect of trade liberalization on wages from other concurrent secular trends in wages at the industry level.

In all our specifications, we include period-fixed effects and industry dummies. This or factor immobility, or both. 
controls for changes in exchange rates (devaluations and appreciations) and industry-specific characteristics so that the impacts of tariffs are not confounded by industry characteristics or by aggregate shocks (related to policy or business cycle). These fixed effects also account for unobservable variables that could induce a spurious correlation between tariffs and wages.

Since our tariff measures vary across industries, any clustering in the residuals $\mu_{i j t}$ in (15) may be exacerbated (Moulton, 1990). In all our regressions, thus, inference is made on the basis of a robust, cluster-corrected estimation of the variance of the error term. In all our results, we report two estimates of the standard errors. In one model, we allow for clustering at the industry level to account for autocorrelation in the residuals at the industry level (that is, for shocks to the industry that may perpetuate in time). In the second model, the errors are clustered at the time-industry level. ${ }^{14}$ Our results are robust to these two models of cluster effects.

The main results from model (15) are reported in Table 1. Columns (1) to (4) correspond to Models 1 to 4, respectively; the standard errors clustered at the industry level are reported within parenthesis while those clustered by industry and time are reported within brackets. We find a positive effect of tariffs on wages, a relationship that is significant at the 10 percent level of statistical significance. These results are not affected by allowing the returns to schooling to vary from period to period (time-varying returns to schooling in column 2) and by allowing both the returns to schooling and age to be time-varying (column 3). Further, the results remain practically unaltered if we also include sector-specific linear trends in the model (columns 4).

Our findings support the view that, ceteris paribus, trade barriers protect workers earnings across the board. ${ }^{15}$ Although these findings are more or less expected, the previous literature is sometimes inconclusive. In Argentina, for instance, Galiani and Sanguinetti (2003) do not find a positive association between tariffs and wages (though they do find a significant association with import penetration measures). Currie and Harrison (1997) and Harrison and Hanson (1999) are other examples where tariffs show up insignificant in wage

\footnotetext{
${ }^{14}$ This is the standard clustering analyzed in Moulton (1990).

${ }^{15}$ Since the model condition on parametric and non-parametric time trends, the correct interpretation of the negative effect of trade liberalization on wages is conditional on any growth effect of that trade reform.
} 
equations. In Attanasio, Goldberg, and Pavcnik (2004), on the other hand, tariffs have a significant impact on the industry premiums and overall wages, and in Revenga (1997), real wages are also found to be affected by tariffs. ${ }^{16}$

\subsection{Tariff Reforms and the Industry Skill Premium}

In this section we test whether sectoral tariffs also affect the skill premium at the industry level. This claim is a corollary of the analytical framework of section 3, where the industry skill premium can arise in equilibrium in the presence of unions (but could arise more generally with imperfect labor mobility across sectors). We want to investigate if these industry skill premiums are, in part, due to the structure of tariff protection across sectors.

Our benchmark regression is:

$$
\ln w_{i j t}=\mathbf{x}_{i j t}^{\prime} \beta_{t}+\sum_{g} \delta_{g t} d S_{i g j t}+\alpha \ln \tau_{j t}+\sum_{g} \phi_{g} d S_{i g j t} \ln \tau_{j t}+I_{j}+Y_{t}+\mu_{i j t}
$$

This model differs from model (15) in that we add interaction terms between the trade policy variable (the $\log$ of tariffs, $\ln \tau)$ and the educational attainment dummies $\left(d S_{i g j t}\right)$. The coefficients of these interactions, $\phi_{g}$, can be interpreted as the differential impact of trade on the wage of individuals with different education, over and above the average effect of trade protection. ${ }^{17}$

Our main findings are reported in Table 2. We estimate the four models described in the previous section (with the standard errors clustered by industry - within parenthesis - and by industry-time - within brackets). In the first row of the table, we show the direct impact of tariffs on average wages. We find evidence of a positive and significant effect of tariffs on the wages of unskilled labor (at the 10 percent level). The magnitudes of the coefficient range from 0.355 to 0.447 .

\footnotetext{
${ }^{16}$ The literature on this topic is very rich. Our review of the evidence is necessarily short, to avoid distracting attention from the main results of our paper. A recent survey on the trade-wages link is Goldberg and Pavcnik (2007).

${ }^{17} \mathrm{We}$ also experimented with interactions of tariffs and age to explore the links between trade protection and tenure. We did not find any statistically significant association between trade policy and returns to age. See below.
} 
The second and third rows report the coefficients of the impact of the sectoral tariffs on the skilled wage premium. Interestingly, we find no evidence of any impact of trade protection on skilled wage premiums in a model that imposes common returns to schooling and tenure across time periods (column 1). In principle, however, we should expect the skill premium to be affected across time by many factors other than trade policy (such as skill biased technical change or changes in labor regulations). In column (2), thus, we allow the returns to schooling to vary from period to period. In column (3), we further allow the returns to tenure to vary from period to period. In all these models, we find that trade protection affects negatively and significantly the returns to higher education. These results are robust (and remain practically unchanged) to the inclusion of sector specific linear trends (see column (4)).

Our findings confirm the intuition uncovered by Figures 3 and 4: after controlling for key confounding factors, reductions in average tariffs lead to increases in the skilled wage premium and to increases in wage inequality. These results appear to be very robust. They are not an artifact of the business cycle or spurious trends since we control for period effects. We claim that our results are neither driven by confounding the effect of tariffs on the skill premiums with unobservable industry fixed characteristics (as industry dummies are included in the regression), not are our findings due to industry specific trends. They are not the result of concurrent confounding policy factors, like labor reforms or industrial policies, since individual characteristics and time varying returns to age and education help control for them. Overall, thus, the results do not seem to be driven by unobservables.

We turn now to a sensitivity analysis. In Table 3, we reproduce the analysis of Table 2 but with a new definition of skills. Here, we classified as skill labor all workers with either a college degree or a complete secondary school degree. This alternative definition of skill could be important especially during the 1970s, when college eduction was much less widespread than it is today. Unskilled workers comprise all individuals with incomplete secondary or lower education. Our findings are robust to this new definition of skills. Tariffs have a direct positive impact on unskilled wages (significant only at the 10 percent level) and a negative impact on the skill premium (significant at the 1 percent level). 
There are three further concerns about the results in Table 2 that we need to address. One concern is that the association of tariffs with the skill premium in the historical data may be driven by the sharp drop in tariffs during the 1970s. Indeed, as pointed out before, the tariff cuts of the 1970s are approximately 5 times larger than the cuts of the liberalization of the 1990s. To rule out this possibility, we experimented by breaking down the historical series and dropping the 1970s from the analysis.

Our main results are reported in Table 4. The first column reproduces column (3) of Table 2 -i.e., the model for 1974-2001 with three educational categories and time-varying returns to schooling and age. In column (2), we exclude the 1970s from the analysis. Our main findings are unaffected by this change in the sample period. Tariffs are shown to have positive effects on average wages and negative and more significant effects on the skill premium. In fact, the impacts on the skill premium are even larger when the 1970s are excluded, strongly suggesting that our results are not driven by the tariffs cuts of this period. In column (3), we exclude all years in the 1974-1982 period, where the tariff cuts were the largest (Figure 3). Once again, our findings are robust to the exclusion of these years.

The second concern is the role of non-tariff barriers like quotas or quantitative restrictions. These are usual instruments of the Argentine trade policy, and provided non-tariff barriers are correlated with tariff barriers, their omission in the regressions can cast doubts on the interpretation of our key results. The problem with non-tariff barriers is that we were unable to construct historical series spanning the period under study. Even simple measures of coverage ratios are unavailable (or very hard to construct). ${ }^{18}$

In principle, if non-tariff barriers were uncorrelated with tariffs, our estimates would be consistent. However, this correlation might be present, for instance if quotas are high in those industries with low tariffs. Nevertheless, using data on tariffs and non-tariff ad-valorem equivalents compiled by Kee, Nicita, and Olarreaga (2006), we find that the correlation between tariffs and non-tariff barriers in Argentina is positive but very small (around 0.03). This suggests that the omission of non-tariff barriers in the main regressions would not be

\footnotetext{
${ }^{18}$ The historical trade data that we put together in this paper does not come electronically. Instead, we had to collect hard copies of trade data for thousands of HS items for many years and to input them manually. Non-tariff barriers are usually implemented through legislative decrees specific to the different industries. Building a historical dataset of norms legislated by decrees is practically unfeasible.
} 
problematic.

We follow two further strategies to account for the role played by non-tariff barriers. One way around the problem of lack of data on NTBs is to exploit the sequencing of trade reforms experienced by Argentina. Berlinski (1994; 2003) has documented that non-tariff barriers were exclusively used during the debt crisis of 1982-1989. Before that, non-tariff barriers were not generally used; after that, they were eliminated prior to the tariff cuts of the liberalization of the 1990s. This suggests a way to check the robustness of our results by further breaking down the historical series. In column (4) of Table 4, for instance, we exclude the 1982-1989 period from the analysis. We find that the impacts of tariffs on average wages are positive, similar in magnitude, but not statistically significant; in contrast, the impacts of tariffs on the skill premium remain negative and statistically significant.

Non-tariff barriers were fully eliminated from 1988 to 1991. Indeed, the elimination of quantitative restrictions was a pre-requisite to the negotiations of the common external tariff of Mercosur (Berlinski, 1994; 2003). Thus, an additional robustness check of the link between tariffs and the skill premium is to run the model on the 1992-2001 sample. Active trade policy during this period comprises only tariff changes. Results in column (5) confirm our previous findings. Tariffs have a positive impact on average wages; this effect is highly significant during the 1990s. Further, tariffs impact negatively, and highly significantly, on the skill premium.

A final concern with the analysis is the potential endogeneity of sectoral tariffs to wages (as in a model of political economy). In our setting, the case for the endogeneity of tariffs is relatively weak because our regressions include a number of control variables that ameliorate this problem, namely time-varying returns to schooling and tenure, individual characteristics, industry effect, time effects, and sectoral trends. The temporal variation in our data is critical to support this claim. For instance, the endogeneity of tariffs caused by political economy arguments is unavoidable in cross-section studies but can be controlled for, to a large extent, with the inclusion in the model of industry dummies, time dummies, and sectoral trends in the pooled historical data. Once we control for all these variables, the level of protection is mostly determined by two factors: the worldwide trend towards trade liberalization and 
the initial level of protection (so that sectors with higher tariffs would face larger tariff cuts, on average). ${ }^{19}$ We argue that these two factors can reasonably be thought of as exogenous in our estimated equations. Indeed, the two processes of trade liberalization in Argentina are entrenched in waves of integration of Latin America to the world. During the 1970s, all the military governments of the Southern cone in Latin America embarked in similar programs of trade and financial liberalization. These programs were the first attempt to undo a large set of regulations enacted during the period of import substitution. The second wave of trade liberalization started in 1989 is edged within an even broader movement of the whole continent towards world trade integration following the Washington Consensus and the GATT agreements.

Furthermore, we claim that pursuing an instrumental variable approach would be necessarily weak given the impossibility of finding reasonable instruments due to the nature of our empirical exercise (which spans thirty years of Argentine recent history). Instead, we exploit here the comparison of the breaks in the trends in tariff reforms and the breaks in the trends in wage inequality (which are arguably exogenous). We believe that our strategy of matching sectoral tariffs to sectoral wages through two episodes of trade liberalization and one episode of reversal to protection provides a valid identification strategy of the effects of trade liberalization on wages and wage inequality.

\subsection{Stolper-Samuelson: The Average Tariff and the Skill Premium}

The Stolper-Samuelson theorem of the Heckscher-Ohlin model predicts that developing countries should experience an increase in the relative wage of unskilled labor after episodes of trade liberalization. However, the majority of the literature has identified increases in wage inequality and in the skill premium following trade reforms. This evidence has been traditionally reconciled with the theoretical model by noticing that the impacts on wages depend on the observed tariff changes which, in turn, depend on the initial level of protection.

However, if this last argument is true, we claim that it should be possible to extract Stolper-Samuelson effects from the data, namely a positive association between the national

\footnotetext{
${ }^{19}$ See also Goldberg and Pavcnik (2005)
} 
average tariff and the skill premium in developing countries (which are abundant in unskilled labor), once the effects of industry tariffs are accounted for. Concretely, our claim is that trade liberalization should favor unskilled labor in unskilled labor abundant countries, conditional on the structure of sectoral protection.

To do this, we set up an empirical model that combines these two impacts of trade: one stemming from the average national tariff and another stemming from the structure of sectoral tariffs. The model is estimated in two stages, as in Goldberg and Pavcnik (2005). In the first stage, we estimate the earnings model in equation (16). From this regression, we collect the estimates of $\delta_{t}$, the economy-wide baseline skill premium. In the second stage, we exploit the time series dimension of our data and regress the estimated skilled premium, $\delta_{t}$, on the $\log$ of the national average tariff $\tau_{t}$ :

$$
\delta_{t}=a+\gamma \ln \tau_{t}+L_{t} \rho+\nu_{t}
$$

where $L_{t}$ is the share of skilled to unskilled workers at time $t$, a control for changes in the composition of labor supply in Argentina. We estimate equation (17) by the method of weighted least squares, using the inverse of the estimates of the variance of the skilled premium from the first stage as weights. In principle, our model could be estimated in one stage. Our two-stage estimation is an attempt to highlight the need to account for the cross-sectional structure of protection in order to identify Stolper-Samuelson effects. ${ }^{20}$

Our results are in Table $5 .^{21}$ Each entry corresponds to an estimate of the parameter $\gamma$ in equation (17), the coefficient of the average national tariff in the second stage regression. For robustness and consistency with our previous specifications, we estimate three models in the first stage: these are models 2 to 4 from Tables 2-4. In addition, we estimate two models for the second stage regression. The first row in Table 5 corresponds to a model of the skill premium on the average tariff only (without including $L_{t}$ ); in the second row, the model also includes the composition of skilled to unskilled labor supply between the regressors. We use

\footnotetext{
${ }^{20}$ Notice that the omission of the aggregate tariff in the first stage does not generate biases because the impacts of the national tariff is embedded in the overall skill premium, which varies by year in our models, or in the survey-period fixed effects.

${ }^{21}$ The first stage is the same as in Table 2.
} 
the industry-clustered standard errors as weights.

Our estimates reveal that the average tariff has indeed a positive effect on the economy-wide, or baseline, skill premium, so that a reduction in tariffs causes this skill premium to decline. The estimates range from 0.127 to 0.187 so that a 10 percentage points increase in the average tariff would increase the baseline skilled premium by between 0.0127 to 0.0187 percentage points. This result is consistent with the simple predictions of the Stolper-Samuelson theorem for a developing country: if Argentina is abundant in unskilled labor, then trade liberalization should cause unskilled wages to increase and thus the skill premium to decline. ${ }^{22}$

These results confirm our claim: conditional on the structure of sectoral tariffs, our evidence using historical data for Argentina provides some support to the standard Stolper-Samuelson prediction regarding trade liberalization and wages in Latin America. In other words, we find that, on the one hand, a particular sectoral tariff benefits the unskilled labor utilized in that industry; on the other, we find that trade liberalization, meaning reductions in the average level of tariff protection, benefits the abundant factor, which, in developing countries, is unskilled labor. In the end, we are able to reconcile the predictions of the standard factor abundance model of trade, amended to incorporate short-run departures like unions, with the empirical evidence for most of Latin America. ${ }^{23}$

\section{Conclusions}

This paper has examined the links between trade liberalization and skill premiums by exploring a historical dataset of Argentine trade policy and labor force surveys for the

\footnotetext{
${ }^{22}$ Compared to major trade partners like the U.S. or the E.U., Argentina is abundant in unskilled labor (Galiani and Sanguinetti, 2003). On the other hand, Argentina is well-endowed in skills relative to other countries in Latin America and in the rest of the developing world. However, Berlinski (1994) has shown a specialization in natural resources and unskilled labor when Argentina is compared with Brazil, the major partner within the region. All this is evidence that Argentina, for practical purposes, can be considered to be, if anything, relatively endowed in unskilled labor rather than in skill labor.

${ }^{23}$ Notice that, given our estimation strategy and the theoretical framework, it is not possible to use our estimates to forecast the trade-induced changes in the relative wages of unskilled workers. The estimates from Table 2 are conditional on the average tariff, and the estimates from Table 5 are conditional on the cross-sectional structure of protection. Our results illustrate how to estimate Stolper-Samuelson effects, rather than to provide structural estimates of the relationship between tariffs and wages.
} 
period 1974-2001. The period under study is one of active and fluctuating trade reforms and wage inequality in Argentina. Tariff reforms accelerated in the late 1970s and early 1980s, stagnated during the 1980s, and picked up further momentum during the 1990s. The skill premium, in contrast, increased during the 1970s, declined during the 1980s, and increased again during the 1990s.

We have produced three pieces of econometric evidence. First, we have found that, ceteris paribus, trade liberalization reduce the average wage of workers in protected industries. Second, we have documented that, in Argentina, there is a skill premium at the industry level. Furthermore, this skill premium is, in part, affected by tariff protection. Finally, we have established that, conditional on the structure of tariffs at the industry level, the average tariff in the economy is positively associated with the average skill premium. This is an important contribution of our work. This finding imply that, once the structure of sectoral protection is controlled for, trade liberalization should decrease wage inequality in Argentina. This result provides a reconciliation of the Stolper-Samuelson predictions with the observed trends in wage inequality in Latin America.

Our core results suggest that a useful modern model of trade reform and wage inequality should combine traditional explanations of the pattern of trade with non-competitive wage setting mechanisms. To support this claim, we have developed a simple factor abundance model (as in Heckscher-Ohlin) where unions set wages of unskilled labor in import competing sectors. While such a model rationalizes our findings, other modeling frameworks with factor specificity are likely to play a role as well. In addition, Atolia (2007) develops an alternative model with capital complementarity of skills that would also allow for a reconciliation of HOS theory. The ultimate lesson is that the Stolper-Samuelson effects predicted for Latin America are found to play a role in shaping the wage distribution, but only after the incorporation of some mechanism for inter-industry wage differences. 


\section{References}

Atolia, M. (2007). "Trade Liberalization and Rising Wage Inequality in Latin America: Reconciliation with HOS Theory," Journal of International Economics, vol. 71 No 2, pp. 467-494.

Attanasio, O., P. Golberg, and N. Pavcnik (2004). "Trade Reforms and Income Inequality in Colombia," Journal of Development Economics, vol. 74, pp. 331-366.

Berlinski, J. (1994). "Post Trade Liberalization Institutional Issues in Argentina," mimeo, Instituto Di Tella Working Paper No 182.

Berlinski, J. (2003). "International Trade and Commercial Policy," in A New Economic History of Argentina, Della Paollera, G. and A. Taylor (eds.), Cambridge University Press.

Blau, F. and L. Kahn (1996). "International Differences in Male Wage Inequality: Institutions Versus Market Forces," Journal of Political Economy 104(4), pp. 791-837.

Bustos, P. (2005). "The Impact of Trade on Technology and Skill Upgrading: Evidence from Argentina," mimeo CREI, Universitat Pompeu Fabra.

Currie, J., and A. Harrison (1997). "Sharing the Costs: The Impact of Trade Reforms on Capital and Labor in Morocco," Journal of Labor Economics, vol. 17, No 3, pp. S44-S71.

Card, D., T. Lemieux, and W. Riddell (2003b). "Unionization and Wage Inequality: A Comparative Study of the U.S., the U.K. and Canada," NBER Working Paper 9473.

Card, D., T. Lemieux, and W. Riddell (2003b). "Unions and The Wage Structure," in J. T. Addison and C. Schnabel (eds), International Handbook of Trade Unions, Edward Elgar, Cheltenham, UK.

Dickens, W. and L. Katz (1986). "Inter-industry Wage Differences and Industry Characteristics," in Lang, K. and J. Leonard, (eds.), Unemployment and the Structure of Labor Markets, Basil Blackwell. 
Dickens, W. and K. Lang (1988). "Labor Market Segmentation and the Union Wage Premium," Review of Economics and Statistics, vol. 70, No 3, pp. 527-530.

Feenstra, R. and G. Hanson (1999). "The Impact of Oursourcing and High-Technology Capital on Wages: Esimates for the U.S., 1972-1990," Quarterly Journal of Economics, 114(3), pp. 907-940.

Feliciano, Z. (2001). "Workers and Trade Liberalization: The Impact of Trade Reforms in Mexico on Wages and Employment," Industrial and Labor Relations Review, Vol. 55, No. 1, pp. 95-115.

Freeman, R. (1982). "Union Wage Practices and Wage Dispersion Within Establishments," Industrial and Labor Relations Review 36(1), pp. 3-21.

Galiani, S. and S. Nickell (1999). "Unemployment in Argentina in the 1990's," Instituto Torcuato Di Tella, WOrking Paper DTE 219.

Galiani, S. and P. Sanguinetti (2003). "The Impact of Trade Liberalization on Wage Inequality: Evidence from Argentina," Journal of Development Economics, vol. 72, pp. 497-513.

Gaston, N. and D. Trefler (1994). "Protection, Trade and Wages: Evidence from U.S. Manufacturing," Industrial and Labor Market Relations Review, vol. 47, pp. 574-93.

Gaston, N. and D. Trefler (1995). "Union Wage Sensitivity to Trade and Protection: Theory and Evidence," Journal of International Economics 39 pp. 1-25.

Gibbons, R. and L. Katz (1992). "Does Unmeasured Ability Explain Inter-industry Wage Differentials?," Review of Economic Studies, vol. 59, pp. 515-35.

Goldberg, P. and N. Pavcnik (2004). "Trade, Inequality, and Poverty: What Do We Know? Evidence from Recent Trade Liberalization Episodes in Developing Countries," Brookings Trade Forum 2004, pp. 223-269. 
Goldberg, P. and N. Pavcnik (2005). "Trade, Wages, and the Political Economy of Trade Protection: Evidence from the Colombian Trade Reforms," Journal of International Economics, vol. 66, pp. 75-105.

Goldberg, P. and N. Pavcnik (2007). "Distributional Effects of Globalization in Developing Countries," Journal of Economic Literature, vol. 45, No 1, pp. 39-82.

Harrison, A. and G. Hanson (1999). "Who Gains From Trade Reforms? Some Remaining Puzzles," Journal of Development Economics, vol. 59, pp. 125-154.

Kee, H., A. Nicita, and M. Olarreaga (2005). "Estimating Trade Restrictiveness Indices," World Bank Policy Research Working Paper 3840.

Kruger, A. and L. Summers (1989). "Efficiency Wages and the Inter-industry Wage Structure," Econometrica, vol. 56, pp. 259-93.

Lawrence, R. and M. Slaughter (1993). "Trade and US wages: Giant Sucking Sound or Small Hiccup?," Brookings Papers on Economic Activity, pp. 161-226.

Leamer, E. (1998). "In search of Stolper-Samuelson Linkages Between International Trade and Lower Wages," in S. Collins (ed.), Imports, Exports, and the American Worker, Brookings Institution.

Marshall, A. (2001). "Fuerzas del Mercado, Política Laboral y Sindicatos: Efectos Sobre la Desigualdad Salarial," 5 Congreso Nacional de Estudios del Trabajo, Argentina.

Moulton, B. (1990). "An Illustration of a Pitfall in Estimating the Effects of Aggregate Variables on Micro Units," Review of Ecnomics and Statistics, pp. 334-338.

Mussa, M. (1978). "Dynamic Adjustment in the Heckscher-Ohlin-Samuelson Model," The Journal of Political Economy, Vol. 86, No. 5, pp. 775-791.

Pavcnik, N. (2003). "What Explains Skill Upgrading in Less Developed Countries," Journal of Development Economics, vol. 71, pp. 311-328. 
Revenga, A. (1997). "Employment and Wage Effects of Trade Liberalization: The Case of Mexican Manufacturing," Journal of Labor Economics, vol. 15, pp. 520-543.

Robertson, R. (2004). "Relative Prices and Wage Inequality: Evidence From Mexico," Journal of International Economics, vol. 64, pp. 387-409.

Sachs, J. and H. Shatz (1994). "Trade and jobs in U.S. manufacturing," Brooking Papers on Economic Activity, pp. 1-84.

Stephan, G. and K. Gerlach (2005). "Wage Settlements and Wage Setting: Results from a Multi-level Model," Applied Economics 37, pp. 2297-2306.

Vogel, T. (2007). "Union Wage Compression in a Right-to-Manage Model," SFB 649 Discussion Paper, Humboldt-Universitat zu Berlin. 
Table 1

The Impacts of Tariffs on log Wages

\begin{tabular}{|c|c|c|c|c|}
\hline & $\begin{array}{l}\text { Model } 1 \\
(1)\end{array}$ & $\begin{array}{l}\text { Model } 2 \\
(2)\end{array}$ & $\begin{array}{c}\text { Model } 3 \\
(3)\end{array}$ & $\begin{array}{l}\text { Model } 4 \\
(4)\end{array}$ \\
\hline Log tariff & $\begin{array}{c}0.357^{*} \\
(0.203) \\
{[0.215]}\end{array}$ & $\begin{array}{c}0.353^{*} \\
(0.206) \\
{[0.216]}\end{array}$ & $\begin{array}{c}0.355^{*} \\
(0.205) \\
{[0.216]}\end{array}$ & $\begin{array}{c}0.412^{*} \\
(0.226) \\
{[0.247]}\end{array}$ \\
\hline $\begin{array}{l}\text { Time-varying } \\
\text { returns to schooling }\end{array}$ & No & Yes & Yes & Yes \\
\hline $\begin{array}{l}\text { Time-varying } \\
\text { returns to age }\end{array}$ & No & No & Yes & Yes \\
\hline Time effects & Yes & Yes & Yes & Yes \\
\hline Industry effects & Yes & Yes & Yes & Yes \\
\hline Sectoral Trends & No & No & No & Yes \\
\hline R-squared & 0.89 & 0.89 & 0.89 & 0.89 \\
\hline Observations & 29053 & 29053 & 29053 & 29053 \\
\hline
\end{tabular}

Notes. Standard errors: in parentheses (clustered by 3-digit industry); in brackets (clustered by industry and time period). The regression includes three educational categories. Skilled labor includes college graduates, semiskilled labor includes workers with secondary school and incomplete college; unskilled labor includes incomplete secondary or less. *: Significant at 10Other controls: age, age squared, gender dummy, head dummy, marital status, and the three (un-interacted) educational dummies). 
Table 2

Tariff Reform and the Industry Skill Premium

\begin{tabular}{lcccc}
\hline \hline & $\begin{array}{c}\text { Model } 1 \\
(1)\end{array}$ & $\begin{array}{c}\text { Model } 2 \\
(2)\end{array}$ & $\begin{array}{c}\text { Model 3 } \\
(3)\end{array}$ & $\begin{array}{c}\text { Model } 4 \\
(4)\end{array}$ \\
\hline log Tariff & $0.355^{*}$ & $0.388^{*}$ & $0.389^{*}$ & $0.447^{*}$ \\
& $(0.200)$ & $(0.211)$ & $(0.210)$ & $(0.231)$ \\
& {$[0.213]$} & {$[0.224]$} & {$[0.224]$} & {$[0.254]$} \\
$\log$ Tariff*SemiSkilled & 0.033 & -0.077 & -0.076 & -0.082 \\
& $(0.031)$ & $(0.055)$ & $(0.056)$ & $(0.058)$ \\
& {$[0.033]$} & {$[0.053]$} & {$[0.054]$} & {$[0.054]$} \\
$\log$ Tariff*Skilled & -0.098 & $-0.355^{* * *}$ & $-0.339^{* * *}$ & $-0.345^{* * *}$ \\
& $(0.067)$ & $(0.124)$ & $(0.123)$ & $(0.121)$ \\
& {$[0.068]$} & {$[0.133]$} & {$[0.131]$} & {$[0.127]$} \\
Time-varying & No & Yes & Yes & Yes \\
returns to schooling & & & & \\
Time-varying & No & No & Yes & Yes \\
returns to age & Yes & Yes & Yes & Yes \\
Time effects & Yes & Yes & Yes & Yes \\
Industry effects & No & No & No & Yes \\
Sectoral Trends & 0.89 & 0.89 & 0.89 & 0.89 \\
\hline R-squared & 29053 & 29053 & 29053 & 29053 \\
Observations & & & & \\
\hline \hline
\end{tabular}

Notes. Standard errors: in parentheses (clustered by 3-digit industry); in brackets (clustered by industry and time period). The regression includes three educational categories. Skilled labor includes college graduates, semiskilled labor includes workers with secondary school and incomplete college; unskilled labor includes incomplete secondary or less. *: Significant at 10\%**: Significant at 5\%***: Significant at 1\% Other controls: age, age squared, gender dummy, head dummy, marital status, and the three (un-interacted) educational dummies). 
Table 3

Tariff Reform and the Industry Skill Premium

Sensitivity to The Definition of Skilled Labor

\begin{tabular}{lcccc}
\hline \hline & $\begin{array}{c}\text { Model 1 } \\
(1)\end{array}$ & $\begin{array}{c}\text { Model } 2 \\
(2)\end{array}$ & $\begin{array}{c}\text { Model 3 } \\
(3)\end{array}$ & $\begin{array}{c}\text { Model } 4 \\
(4)\end{array}$ \\
\hline log Tariff & $0.359^{*}$ & $0.401^{*}$ & $0.402^{*}$ & $0.455^{*}$ \\
& $(0.199)$ & $(0.208)$ & $(0.207)$ & $(0.229)$ \\
& {$[0.212]$} & {$[0.223]$} & {$[0.222]$} & {$[0.253]$} \\
$\log$ Tariff*Skilled & -0.002 & $-0.158^{* * *}$ & $-0.154^{* *}$ & $-0.154^{* * *}$ \\
& $(0.033)$ & $(0.064)$ & $(0.065)$ & $(0.066)$ \\
& {$[0.035]$} & {$[0.061]$} & {$[0.062]$} & {$[0.061]$} \\
Time-varying & No & Yes & Yes & Yes \\
returns to schooling & & & & \\
Time-varying & No & No & Yes & Yes \\
returns to age & & & & \\
Time effects & Yes & Yes & Yes & Yes \\
Industry effects & Yes & Yes & Yes & Yes \\
Sectoral Trends & No & No & No & Yes \\
\hline R-squared & 0.89 & 0.89 & 0.89 & 0.89 \\
Observations & 29053 & 29053 & 29053 & 29053 \\
\hline \hline
\end{tabular}

Notes. Standard errors: in parentheses (clustered by 3-digit industry); in brackets (clustered by industry and time period). The regression includes two educational categories. Skilled labor includes college and secondary school graduates, and unskilled labor includes workers with less than complete secondary school. *: Significant at $10 \% * *$ : Significant at 5\%***: Significant at 1\% Other controls: age, age squared, gender dummy, head dummy, marital status, and the three (un-interacted) educational dummies). 
Table 4

Robustness Check

\begin{tabular}{lccccc}
\hline \hline & & & & $1974-1981$ & \\
& $(1)$ & $(2)$ & $(3)$ & $(4)$ & $(5)$ \\
\hline log tariff & $0.389^{*}$ & $0.456^{*}$ & $0.595^{*}$ & 0.335 & $0.128^{* * *}$ \\
& $(0.210)$ & $(0.248)$ & $(0.324)$ & $(0.260)$ & $(0.054)$ \\
& {$[0.224]$} & {$[0.267]$} & {$[0.317]$} & {$[0.257]$} & {$[0.043]$} \\
log tariff*semiskilled & -0.076 & -0.088 & -0.134 & $-0.127^{* *}$ & $-0.128^{* * *}$ \\
& $(0.056)$ & $(0.072)$ & $(0.094)$ & $(0.078)$ & $(0.071)$ \\
& {$[0.054]$} & {$[0.072]$} & {$[0.083]$} & {$[0.056]$} & {$[0.049]$} \\
log tariff*skilled & $-0.339^{* * *}$ & $-0.420^{* * *}$ & $-0.487^{* * *}$ & $-0.461^{* * *}$ & $-0.442^{* * *}$ \\
& $(0.123)$ & $(0.148)$ & $(0.183)$ & $(0.142)$ & $(0.165)$ \\
Time-varying & {$[0.131]$} & {$[0.158]$} & {$[0.182]$} & {$[0.142]$} & {$[0.111]$} \\
returns to schooling & Yes & Yes & Yes & Yes & Yes \\
Time-varying & & & & & \\
returns to age & Yes & Yes & Yes & Yes & Yes \\
Time effects & Yes & Yes & Yes & Yes & Yes \\
Industry effects & Yes & Yes & Yes & Yes & Yes \\
\hline R-squared & 0.89 & 0.89 & 0.85 & 0.89 & 0.35 \\
Observations & 29053 & 24072 & 21783 & 21126 & 11131 \\
\hline \hline
\end{tabular}

Notes. Standard errors: in parentheses (clustered by 3-digit industry); in brackets (clustered by industry and time period). The regression includes two educational categories. Skilled labor includes college and secondary school graduates, and unskilled labor includes workers with less than complete secondary school. *: Significant at $10 \% * *$ : Significant at 5\%***: Significant at $1 \%$ Other controls: age, age squared, gender dummy, head dummy, marital status. 
Table 5

The Average Tariff and the Skill Premium

\begin{tabular}{lccc}
\hline \hline & $\begin{array}{c}\text { Model 2 } \\
(1)\end{array}$ & $\begin{array}{c}\text { Model 3 } \\
(2)\end{array}$ & $\begin{array}{c}\text { Model 4 } \\
(3)\end{array}$ \\
\hline Average national tariff & $\begin{array}{c}0.139^{*} \\
(0.076)\end{array}$ & $\begin{array}{c}0.128^{*} \\
(0.075)\end{array}$ & $\begin{array}{c}0.127^{*} \\
(0.070)\end{array}$ \\
$R^{2}$ & 0.19 & 0.19 & 0.19 \\
\cline { 2 - 4 } Average national tariff & $0.182^{* *}$ & $0.172^{* *}$ & $0.187^{* *}$ \\
(with supply composition) & $(0.082)$ & $(0.081)$ & $(0.076)$ \\
$R^{2}$ & 0.21 & 0.19 & 0.19 \\
\hline Observations & 39 & 39 & 39 \\
\hline \hline
\end{tabular}

Notes. Standard errors in parentheses. The results correspond to the coefficient of the average national tariff on the average skill premium from a two-stages regression model. In the first stage, we run the model in equation (16) and recover the skill premium. In the second stage, we regress the skill premium on the average national tariff (using the time series dimension of the data only). We estimate three models in the first stage, Models 2 to 4 in Table 2. The first row in the table corresponds to a model of the skill premium on the average tariff only. In the second row, the model also includes the composition of skill to unskill labor supply. *: Significant at 10\%**: Significant at 5\% ***: Significant at $1 \%$ 